\title{
FEEDING DRY OLIVE CAKE MODIFIES SUBCUTANEOUS FAT COMPOSITION IN LAMBS, NOTING CAKE RESISTANCE TO DEGRADATION AND PEROXIDATION
}

\author{
Raúl Vera $^{1 *}$, Claudio Aguilar ${ }^{1}$, Rodrigo Lira ${ }^{1}$, Paula Toro ${ }^{1}$, Luis Barrales ${ }^{1}$, Iván Peña ${ }^{1}$, \\ Fernando Squella², Patricio Pérez ${ }^{3}$, Javiera Quenaya ${ }^{1}$, Hanja Yutronic ${ }^{1}$, and Ignacio Briones ${ }^{4}$
}

\begin{abstract}
The purpose of this experiment was to determine the extent to which lamb carcass quality and fat composition could be altered by applying a dry olive cake-based ration instead of a conventional ration or pasture feeding. Three treatments were compared in a completely randomized experiment using 36 single male Suffolk Down lambs with an initial age and live weight of $80 \mathrm{~d}$ and $25 \mathrm{~kg}$, respectively. The three treatments were: (a) suckling lambs kept with their mothers on annual Mediterranean grassland (GRAZE); (b) weaned stall-fed lambs on a control ration (CONC); and (c) weaned stall-fed lambs on an olive cake-based ration (CAKE). At the end of the 28-d experimental period, lambs were slaughtered, carcass quality evaluated, and samples of subcutaneous fat analyzed for fatty acids. Treatments did not differ in weight gain or carcass weight and quality, but highly significant differences were found in several fatty acid contents. CAKE animals had reduced palmitic acid as well as increased oleic and stearic acid contents. Atherogenic and thrombogenic indices improved with cake feeding. Principal component and discriminant analyses clearly differentiated treatments suggesting they could be applicable for traceability purposes. A laboratory experiment demonstrated that with or without added vitamin E, the dry olive cake did not alter its lipid properties with increased storage time.
\end{abstract}

Key words: sheep; dry olive cake; fatty acids, body composition.

\section{INTRODUCTION}

There is an increasing interest in developing food alternatives with a healthier nutrient profile not yet available, centered on the contents and composition of the lipid fraction (Demeyer and Doreau, 1999; NRC, 2002; MacRae et al., 2005). This trend is reflected in the worldwide increase and consumption of olive oil (FAO, 2007), but unfortunately, its production can be associated with negative environmental impacts because of its waste product disposal (Junta de Andalucía, 2001), every metric ton of oil produced can generate three or more tons of difficult to dispose residues.

${ }^{1}$ Pontificia Universidad Católica, Facultad de Agronomía e Ingeniería Forestal, Casilla 6177, Santiago, Chile. *Corresponding author (rverai@uc.cl).

${ }^{2}$ Instituto de Investigaciones Agropecuarias INIA, Centro Experimental Hidango, Casilla 3, Litueche, Chile.

${ }^{3}$ Universidad de Chile, Facultad de Ciencias Veterinarias y Pecuarias, Av. Santa Rosa 11735, La Pintana, Santiago, Chile.

${ }^{4}$ Fondo para la Innovación Agraria, Ministerio de Agricultura, Loreley 1582, La Reina, Santiago, Chile.

Received: 13 October 2008.

Accepted: 28 January 2009.
Meats, mainly lamb, are sometimes discriminated against due to their perceived high fat content and, in particular, high saturated fatty acid concentration of that are considered an atherogenic and thrombogenic risk (Givens, 2005). These aspects have led some authors to suggest the need to adapt meat products to changing demand (Anderson, 2001).

Pasture-raised fat lamb production is the main animal product of small and medium farms in South Central Chile, a region where olive (Olea europaea L.) plantations are rapidly expanding. There is therefore an opportunity to use olive oil byproducts as a supplement for sheep that are characteristically raised on degraded, low yielding, annual Mediterranean-like grasslands (Ovalle and Squella, 1996). Olive oil byproducts can be used in ruminant feeding although their nutritive value varies depending on the oil extraction method, their subsequent processing, and to a lesser extent, olive variety, and environmental conditions. Nevertheless, diverse authors have reported satisfactory animal performance when these byproducts were fed to sheep (Hadjipanayiotou, 1994; Khorchani et al., 1997; Cabiddu et al., 2004; Chiofalo et al., 2004; Molina Alcaide et al., 2005). 
The modern oil extraction method is a two-phase procedure whereby crushed olives are cold-pressed to obtain high quality extra-virgin oil. The residual olive cake contains substantial amounts of oil that can or cannot be further extracted. It can also be centrifuged to remove part of the crushed stones, resulting in a "partly destoned olive cake" (see nomenclature in Olive Oil Source, 2007). Thus, interest is created by the combination of a large amount of unused olive residues with the need to intensify and differentiate fat lamb production in Central Chile. One alternative to differentiate lamb meat is by altering the fatty acid profile of the carcasses towards a more favorable balance between saturated and unsaturated fatty acids that would have a positive impact on consumer health. This issue has received some attention from the point of view of using Mediterranean pastures (Cabiddu et al., 2005) and their influence on the milk content of polyunsaturated fatty acids. That is not the case for olive residues that are naturally high in monounsaturated fatty acids.

Thus, the objective of the present study was to assess the extent to which lamb carcass quality and fatty acid composition were modified by feeding an olive cakebased mixed ration, compared to pasture-raised suckling lambs (farmer control) and to stall-fed lambs on a completely mixed, conventional ration. A secondary aim was to determine the stability of dry olive cake over time since there was no prior information on its stability.

\section{MATERIALS AND METHODS}

\section{Laboratory experiment}

Triplicate samples of olive cake were obtained from a modern, two-phase, oil processing plant. Samples were pooled and immediately mixed with $0,100,400$, or $800 \mathrm{mg}$ vitamin $\mathrm{E}$ per $\mathrm{kg}$ of fresh material $(32 \% \mathrm{DM})$. Samples were dried at $60{ }^{\circ} \mathrm{C}$ and stored for $0,14,30,90$, 180 , or $392 \mathrm{~d}$ in airtight containers at room temperature, then analyzed for free fatty acids (FFA, expressed as a percentage of oleic acid) and the peroxide index (PI, meq $\mathrm{kg}^{-1}$ fat). The fatty acid profile of the samples was determined at days 90 and 180 of storage.

\section{Animal experiment}

The experiment was conducted at the Hidango Research Field Station, Instituto de Investigaciones Agropecuarias INIA, located in Central Chile (340. $6^{\circ} \mathrm{S}$, $71^{\circ} 47^{\prime} \mathrm{W}, 296$ m.a.s.1.), which has a distinct Mediterranean climate and vegetation. The trial was carried out during the spring season, between 20 October and 22 November 2006, following an 8-d adaptation period. Experimental protocol followed approved animal health and welfare guidelines.

\section{Treatments}

Three treatments were compared in a completely randomized experiment using 36 single male Suffolk Down lambs with an initial age and live weight of $80 \pm$ $4 \mathrm{~d}$ and $25.1 \pm 2.5 \mathrm{~kg}$, respectively. The three treatments were: (a) suckling lambs kept with their mothers on annual grassland, GRAZE; (b) lambs weaned and fed a control ration, CONC; and (c) weaned lambs fed an olive cakebased ration, CAKE (Table 1). Chemical composition is shown in Table 2.

The olive cake was manually processed as it emerged from a continuous, two-phase oil extraction plant over several consecutive days. It was immediately passed through a screen to remove part of the ground stones, mixed with vitamin $\mathrm{E}\left(800 \mathrm{mg} \mathrm{kg}^{-1}\right)$, and stored in air tight containers in a freezer until further processing. The partially destoned olive cake was then dried in a forced air oven at $60^{\circ} \mathrm{C}$, ground, and mixed with the remaining ration ingredients Chemical composition is shown in Table 3.

GRAZE ewes and lambs were continuously grazed on a 19 ha annual Mediterranean-like grassland at a stocking rate of 11 ewe equivalents per ha, and used as a farmer control. No attempt was made to measure their forage or milk intake.

Table 1. Composition of the CONC and CAKE rations.

\begin{tabular}{lcc}
\hline Ingredients & CONC & CAKE \\
\hline Ground alfalfa hay, g kg-1 DM & 251 & 0 \\
Ground maize, g kg DM & 267 & 146 \\
Molasses, liquid, g kg-1 DM & 97 & 97 \\
Soybean meal, g kg-1 DM & 275 & 323 \\
Dry olive cake, g kg-1 DM & 0 & 323 \\
Sodium bicarbonate, g kg-1 DM & 9.7 & 9.7 \\
Chopped Long-stemmed alfalfa hay, $\mathrm{g} \mathrm{kg}^{-1} \mathrm{DM}$ & 97 & 97 \\
Complete mineral and vitamin supplement, $\mathrm{g} \mathrm{d}^{-1}$ animal $^{-1}$ & 5 & 5 \\
\hline
\end{tabular}

CONC: lambs weaned and fed a control ration; CAKE: weaned lambs fed an olive cake-based ration. 
Table 2. Chemical composition of the two stall-fed diets.

\begin{tabular}{lcr}
\hline Chemical parameters & CONC & CAKE \\
\cline { 2 - 3 } Crude protein & 219.0 & 191.1 \\
Ether extract & 18.7 & 82.3 \\
Neutral detergent fiber & 287.8 & 327.2 \\
Acid detergent fiber & 153.3 & 142.4 \\
Acid detergent lignin & 31.2 & 67.3 \\
Ash & 78.2 & 93.6 \\
In vitro dry matter digestibility & 776.0 & 714.0 \\
\hline
\end{tabular}

CONC: lambs weaned and fed a control ration; CAKE: weaned lambs fed an olive cake-based ration; DM: dry matter.

\section{Animal management}

CONC and CAKE lambs were housed in $1.4 \mathrm{~m}^{2}$ individual pens and gradually adapted to their diets over an 8-d period. Adaptation to the experimental diets was uneventful. The two experimental diets were offered once a day, in the morning, and amounts of up to $280 \mathrm{~g}$ $\mathrm{d}^{-1}$ (NRC, 2007) were estimated to satisfy their calculated maintenance and growth requirements. The amount offered was adjusted weekly, with $1080 \mathrm{~g} \mathrm{~d}^{-1}$ (as fed) in week 1 to $1300 \mathrm{~g} \mathrm{~d}^{-1}$ in week 4 . Orts were collected daily before the morning feeding and composited weekly for each animal. Samples were dried in a forced air oven at $60{ }^{\circ} \mathrm{C}$. Daily DM intake of individual animals was calculated by subtracting orts from the amount of feed offered. Weekly samples of feed and individual orts were submitted for chemical analyses. All animals were slaughtered at the end of the $28 \mathrm{~d}$ experimental period and approved, humane procedures over a 2-d period were followed. Detailed carcass analyses were carried out as described by Cañeque and Sañudo (2005).

\section{Chemical analysis}

Feed samples along with individual and weekly orts were analyzed (AOAC, 2007) for crude protein (CP), ether extract (EE), neutral detergent fiber (NDF), acid detergent fiber (ADF), lignin in ADF (ADL), ash, and in vitro DM digestibility (IVDMD).

Subcutaneous fat samples were taken at slaughter, immediately chilled, and later frozen, prior to determining fatty acids. Lipids were extracted according to Folch et al. (1956) and Bligh and Dyer (1959). Following overnight esterification with a methanol solution in $1 \mathrm{M} \mathrm{HCl}$, methyl esters were separated and quantified by gas-liquid chromatography following Chilean Norm 2550 (INN, 2001).

Free fatty acids (FFA) and peroxide value (PV) in the olive cake were determined following European norms for olive oil analysis (TDC-Olive, undated). Total polyphenols and condensed tannins were analyzed by the Folin-
Table 3. Chemical composition of the olive cake (DM basis, unless otherwise specified).

\begin{tabular}{lc}
\hline Analysis & Value \\
\hline Crude protein, \% & 6.2 \\
Ether extract, \% & 16.5 \\
Neutral detergent fiber, \% & 32.0 \\
Acid detergent fiber, \% & 25.5 \\
Acid detergent lignin, \% & 15.5 \\
Polyphenols, non tannin, \% & 1.1 \\
Polyphenols, tannin, \% & 0.13 \\
Condensed tannins, \% & 0.001 \\
\hline
\end{tabular}

Fatty acids, $\mathrm{g} 100 \mathrm{~g}^{-1}$ fat:

C14:0 tr

C14:1 tr

C16:0 13.64

C16:1 n7 cis $\quad 0.92$

C17:0 0.1

C17:1 0.2

C18:0 1.84

C18:1 n9 cis $\quad 73.31$

C18:2 n6, 9 all cis $\quad 9.16$

C18:3 n3, 6, 9 all cis $\quad 0.83$

tr: traces.

Ciocalteu, butanol-HCl, and polyvinylpolypyrrolidone techniques (Makkar, 2003).

\section{Statistical analyses}

All statistical analyses were carried out with SAS (SAS Institute, 2002). The laboratory experiment was analyzed as a factorial experiment of vitamin $\mathrm{E} \mathrm{x}$ storage time followed by regression of lipid degradation indices on storage time. Individual animal performance data, including carcass parameters, were analyzed as a completely randomized design. Percentage fatty acid content showed heterogeneous variances and values were transformed (square root) prior to statistical analysis. A multivariate analysis of variance (MANOVA) was carried out on the fatty acid profile of subcutaneous fat which was followed by individual analysis of variance for each fatty acid.

\section{RESULTS}

\section{Laboratory experiment}

Storage time only affected FFA content of samples between days 30 and 90 , with a decrease from 4.06 to $2.81 \%(\mathrm{p}<0.05)$, and remained essentially constant before and after. Neither the addition of vitamin E, nor its interaction with storage time were significant $(p>$ 
0.05). Moreover, PV only changed between days 30 and 90 of storage, from 9.39 to $0.99 \mathrm{meq} \mathrm{kg}^{-1}$ fat $(\mathrm{p}<$ $0.05)$. As before, vitamin $E$ levels and the interaction with storage days did not significantly influence PV $(p>0.05)$. Regressions of both FFA and PV on the square root of days were significant but moderate (adjusted $\mathrm{R}^{2}$ of 0.29 and 0.66 , respectively, $\mathrm{p}<0.05$ ), suggesting that there was only a modest effect of storage time on lipid degradation. Storage time (90 vs. 180 d) did not influence the percentage of individual fatty acids $(p>0.05)$ with the exception of linolenic acid that decreased from $1.01 \%$ on day 90 to $0.65 \%$ on day $180(\mathrm{p}<0.05)$.

\section{Animal experiment}

The olive cake used in the diet had a high residual EE content (16.5\%). Corresponding values for CP, $\mathrm{NDF}, \mathrm{ADF}$, and ADL were 5.6, 32.0, 25.5, and 14.5\%, respectively. Calculated consumption of major fatty acids in the stall-fed treatments is shown in Table 4. Olive cake supplied $90 \%$ of the total oleic acid consumed in the CAKE treatment.

Initial age and live weight, as well as final live weight and carcass weight did not differ between treatments ( $\mathrm{p}>$ 0.05; Aguilar et al., 2009), whereas DM intake of the two concentrate diets was affected by diet composition. Mean individual intakes of CONC and CAKE were 1.07 and $0.99 \mathrm{~kg} \mathrm{DM} \mathrm{d}^{-1}$, respectively $(\mathrm{p}<0.05)$. There were also significant differences in the chemical composition of the diet consumed, except for ADF.

There were few differences in carcass parameters
(Aguilar et al., 2009), but the most significant was the amount of pelvic and kidney fat weighing 114, 94, and $164 \mathrm{~g}(\mathrm{p}<0.001)$ in the GRAZE, CONC, and CAKE treatments, respectively. Subcutaneous fat depth and rib eye area did not differ between treatments $(p>0.05)$.

A multiple analysis of variance (MANOVA) was conducted to determine the effects of treatments on the vector of subcutaneous fatty acids. The resulting Wilks' Lambda test was highly significant $(\mathrm{p}<0.0001)$ indicating differences between treatments. Subsequent pair wise comparisons for the respective vectors indicated that all three contrasts were also highly significant (Wilks' Lambda test, $\mathrm{p}<0.0001$ ), denoting that carcasses of the three treatments differed one from the other in terms of fatty acid profiles. Values and significance of the discriminant functions are shown in Table 5 and the respective standardized coefficients are listed in Table 6.

Standardized coefficients of the first discriminant function showed higher weights associated with $\mathrm{C} 18: 1$ and $\mathrm{C} 18: 0$, followed by lower weights for $\mathrm{C} 16: 0$ and C14:0. The second function was also greatly influenced by the same fatty acids, although with reduced weights. Both functions correctly classified all 36 carcasses to their respective treatments. This was followed by univariate analysis of variance of each fatty acid and of meaningful ratios among them (Table 7). Important quantitative differences in the concentration of palmitic, stearic, myristoleic, oleic, and total saturated and unsaturated fatty acids were found. Significant differences were also found in important indices of fat "healthiness" as

Table 4. Fatty acid content and intake of the two stall-fed diets.

\begin{tabular}{|c|c|c|c|c|}
\hline & \multicolumn{2}{|c|}{ CONC } & \multicolumn{2}{|c|}{ CAKE } \\
\hline & Content & Intake & Content & Intake \\
\hline & $\%$ & $\mathrm{~g} \mathrm{~d}^{-1}$ & $\%$ & $\mathrm{~g} \mathrm{~d}^{-1}$ \\
\hline C16:0 & 17.06 & 3.02 & 14.89 & 10.41 \\
\hline C16:1 & 0.13 & 0 & 0.24 & 0.58 \\
\hline C18:0 & 3.73 & 0.41 & 3.14 & 1.64 \\
\hline C18:1 & 19.78 & 7.84 & 41.48 & 52.39 \\
\hline Linoleic (C18:2) & 33.73 & 16.14 & 34.78 & 16.25 \\
\hline Linolenic (C18:3) & 7.63 & 0.84 & 4.14 & 1.39 \\
\hline
\end{tabular}

CONC: lambs weaned and fed a control ration; CAKE: weaned lambs fed an olive cake-based ration.

Table 5. Results of the discriminant analysis performed on $\mathbf{1 5}$ fatty acids of subcutaneous fat.

\begin{tabular}{lcccc}
\hline $\begin{array}{l}\text { Discriminant } \\
\text { unction }\end{array}$ & Eigenvalues & $\begin{array}{c}\text { Relative } \\
\text { contribution }\end{array}$ & $\begin{array}{c}\text { Canonical } \\
\text { correlation }\end{array}$ & $\begin{array}{c}\text { Wilds Lambda } \\
\mathbf{p}<\end{array}$ \\
\hline 1 & 11.9799 & 0.6823 & 0.961 & 0.001 \\
2 & 5.57853 & 0.3177 & 0.921 & 0.001 \\
\hline
\end{tabular}


Table 6. Standardized coefficients of the discriminant functions.

\begin{tabular}{lll}
\hline Fatty acid & Function $\mathbf{1}$ & Function $\mathbf{2}$ \\
\hline $\mathrm{C} 12: 0$ & -0.0335788 & -0.665572 \\
$\mathrm{C} 13: 0$ & 0.25389 & 0.765942 \\
$\mathrm{C} 14: 0$ & 4.81938 & 2.30217 \\
$\mathrm{C} 15: 0$ & 1.41596 & 0.642149 \\
$\mathrm{C} 16: 0$ & 5.26652 & 2.44607 \\
$\mathrm{C} 17: 0$ & -0.264448 & -0.336018 \\
$\mathrm{C} 18: 0$ & 9.04722 & 4.212 \\
$\mathrm{C} 20: 0$ & 1.41989 & 1.28459 \\
$\mathrm{C} 14: 1$ & 1.32736 & 0.489709 \\
$\mathrm{C} 16: 1$ & 2.08833 & 1.75737 \\
$\mathrm{C} 16: 1 \mathrm{t}$ & 0.397292 & 0.0189377 \\
$\mathrm{C} 17: 1$ & 0.494981 & -1.30247 \\
$\mathrm{C} 18: 1$ & 7.11084 & 4.65246 \\
$\mathrm{C} 18: 2$ & 0.547281 & 0.184613 \\
$\mathrm{C} 18: 3$ & 1.27469 & 0.643089 \\
\hline
\end{tabular}

shown in Table 6. Following the procedure by Kelsey et al. (2003), stearoyl-CoA desaturase (SCD) indices were calculated based on the composition of subcutaneous fat, but no significant differences $(p>0.05)$ were detected among the three treatments. On the other hand, the (C18:0 + C18:1)/C16:0 ratio (Bonanome and Grundy, 1988) differed significantly between treatments $(\mathrm{p}<0.05)$ with values of 2.07, 2.80, and 3.47 for GRAZE, CONTROL, and CAKE, respectively.

Correlations among subcutaneous fatty acids across treatments are shown in Table 8. Oleic acid (C18:1) content of the carcasses was linearly and negatively related to total saturated fatty acids, as well as with all the fatty acids with C chain less than 17, and the content of polyunsaturated fatty acids (PUFA) was also negatively correlated. Similarly, palmitic (C16:0) and stearic (C18:0) acid content were negatively related. The negative relationship between oleic and palmitic acids was steep, with a standardized regression coefficient of $-0.789(\mathrm{p}<0.001)$.

To simplify results, a principal component analysis of the fatty acid matrix was carried out and partialled out for the treatment effect so that the resulting components would be independent of treatment effects (PARTIAL option in PRINCOMP of SAS). Analysis resulted in four components that accounted for $82 \%$ of the total variance. The four principal components (PC 1-4) are shown in Table 9.

\section{DISCUSSION}

\section{Cake conservation}

Production of olive cake is limited to 6-8 weeks per year; therefore, it is desirable to safely conserve it over extended periods if it is to be used as a ration ingredient on a regular basis.

The amount of lipid peroxides found in the cake was small in absolute terms and very low in comparison with data reported by Amro et al. (2002) for butanol extracts of olive cake. In fact, olive oil is more resistant to peroxidation than other commercial vegetable oils ( $\mathrm{Naz}$ et al., 2004), and this can contribute to the stability of the cake. Lipid peroxides are fairly stable at room temperature but break down over time, resulting in aromatic compounds associated with rancidity (Halliwell, 2001), fact which could explain the reduction observed between days 30 and 90. It is interesting to note that Barstov and Bomstein (cited by Puchal Mas and Mascarell, 1999) reported a PV of 56.6 meq kg-1 in unsupplemented broiler carcass fat and $45.1 \mathrm{meq} \mathrm{kg}^{-1}$ when supplemented with 40 $\mathrm{mg} \mathrm{kg}^{-1}$ of vitamin $\mathrm{E}$. This suggests that vitamin $\mathrm{E}$ levels, and possibly Se, should be checked in rations with a high content of unsaturated fatty acids.

The amount of FFA in the cake was somewhat higher than what is generally found in virgin and other olive oils (TDC OLIVE, undated), and as previously mentioned, change over time could have been related to degradation. Nevertheless, modest changes in PV and FFA over time suggest that dry olive cake (85-90\% DM) can be conserved for extended periods without adding vitamin $\mathrm{E}$, and without any significant alterations in its composition. No comparable literature data were found, but the enduring conservation of the cake can be related to the naturally present phenolic antioxidants in olives that amounted to about $1 \%$ (Table 3), and are known for their high potency (De Leonardis et al., 2007).

\section{Cake composition}

Destoned, unexhausted olive cake, originating from the two-phase process of oil extraction in Spain, contains around 5.3\% CP, 75\% NDF, and 12\% EE (López Gallego, 2002), whereas exhausted, partially destoned cake contains $10.6 \% \mathrm{CP}, 63 \% \mathrm{NDF}$, and $2.7 \% \mathrm{EE}$ (Aguilera and Molina, 1986), and a variable in vitro digestibility generally less than $40 \%$. The cake used in the present experiment was of considerably higher quality due to its higher $\mathrm{CP}$ and $\mathrm{EE}$, and much lower NDF. Part of the difference was surely related to differences in oil extraction and destoning procedures.

López Gallego (2002) studied the effect of including 10,20 , or $30 \%$ cake in a concentrate ration that included maize (Zea mays L.), barley (Hordeum vulgare L.), and soybean (Glycine max [L.] Merr.) meal when feeding male and female lambs with $18 \mathrm{~kg}$ initial live weight for 31-34 d. The author found that individual weight gains decreased with increasing cake proportion, from 286 to 272 and $264 \mathrm{~g} \mathrm{~d}^{-1}$, respectively, whereas concentrate 
Table 7. Fatty acid content of subcutaneous fat.

\begin{tabular}{|c|c|c|c|c|}
\hline Fatty acid & GRAZE & CONC & CAKE & $\mathbf{P}<$ \\
\hline & \multicolumn{4}{|c|}{$\mathrm{g} 100 \mathrm{~g}^{-1}$ of total fatty acids } \\
\hline C12:0 & $0.9717 \mathrm{a}$ & $0.5285 b$ & $0.3531 \mathrm{~b}$ & 0.0002 \\
\hline C13:0 & 0.05785 & 0.06011 & 0.05786 & NS \\
\hline C14:0 & $9.0808 \mathrm{a}$ & $4.8149 \mathrm{~b}$ & $4.2653 b$ & 0.0001 \\
\hline $\mathrm{C} 15: 0$ & $1.22341 \mathrm{a}$ & $0.64948 b$ & $0.54296 b$ & 0.0001 \\
\hline C16:0 & $25.863 \mathrm{a}$ & $22.781 b$ & $19.959 \mathrm{c}$ & 0.0001 \\
\hline $\mathrm{C} 17: 0$ & $1.4595 b$ & $1.9452 \mathrm{a}$ & $1.2972 b$ & 0.0001 \\
\hline C18:0 & $17.231 \mathrm{~b}$ & $18.625 \mathrm{ab}$ & $20.860 \mathrm{a}$ & 0.0493 \\
\hline C20:0 & $1.2287 \mathrm{a}$ & $0.5802 b$ & $0.6925 b$ & 0.0004 \\
\hline C14:1 & $0.53877 \mathrm{a}$ & $0.25506 \mathrm{~b}$ & $0.20392 b$ & 0.0001 \\
\hline C16:1 & 1.3523 & 1.5485 & 1.0284 & 0.0522 \\
\hline C16:1t & $0.6301 b$ & $1.1411 \mathrm{a}$ & $0.6845 b$ & 0.0085 \\
\hline $\mathrm{C} 17: 1$ & $0.56223 \mathrm{a}$ & $0.63728 \mathrm{a}$ & $0.39001 b$ & 0.0023 \\
\hline C18:1 & $35.621 \mathrm{a}$ & $43.513 b$ & $47.042 \mathrm{c}$ & 0.0001 \\
\hline C18:2 n-6 & 1.5817 & 1.3015 & 1.4436 & NS \\
\hline C18:3 n-3 & $0.6321 \mathrm{a}$ & $0.1955 b$ & $0.1313 b$ & 0.0001 \\
\hline Others & $1.8972 \mathrm{a}$ & $1.3927 \mathrm{~b}$ & $0.9942 \mathrm{c}$ & 0.0001 \\
\hline SFA & $57.116 \mathrm{a}$ & $49.984 b$ & $48.027 b$ & 0.0001 \\
\hline MUFA & $38.704 a$ & $47.095 \mathrm{~b}$ & $49.349 b$ & 0.0001 \\
\hline PUFA & $2.2825 \mathrm{a}$ & $1.5281 \mathrm{~b}$ & $1.6299 b$ & 0.0203 \\
\hline n-3 total & $1.9295 \mathrm{a}$ & $0.8069 b$ & $0.8788 b$ & 0.0001 \\
\hline$n-6$ total & 1.5817 & 1.3015 & 1.4436 & NS \\
\hline$n-6 / n-3$ & $0.8329 \mathrm{~b}$ & $1.9714 \mathrm{a}$ & $1.8667 \mathrm{a}$ & 0.0001 \\
\hline$(\mathrm{C} 18: 0+\mathrm{C} 18: 1) / \mathrm{C} 16: 0$ & $2.0698 \mathrm{c}$ & $2.7990 \mathrm{~b}$ & $3.4766 \mathrm{a}$ & 0.0001 \\
\hline PUFA/SFA & 0.0399 & 0.0304 & 0.0343 & NS \\
\hline MUFA/SFA & $0.7229 b$ & $0.9795 \mathrm{a}$ & $1.0758 \mathrm{a}$ & 0.0001 \\
\hline
\end{tabular}

Values with different letters are significant differences $(\mathrm{p}<0.05)$.

GRAZE: suckling lambs kept with their mothers on annual grassland; CONC: weaned lambs fed a control ration; CAKE: weaned lambs fed an olive cake-based ration; SFA: saturated fatty acids; MUFA: monounsaturated fatty acids; PUFA: polyunsaturated fatty acids; NS: non significant.

consumption increased slightly from 1051 to $1126 \mathrm{~g} \mathrm{~d}^{-1}$. This clearly contrasts with the present lack of differences in intake between the CONC and CAKE treatment which contained $33 \%$ olive cake. This fact can be linked to the considerable differences in the composition of the present diets compared with those used by López Gallego (2002), and also due to the differences in cake quality discussed above.

EE content of the CAKE diet was high $\left(82 \mathrm{~g} \mathrm{~kg}^{-1}\right)$ and led to a $56 \mathrm{~g} \mathrm{~d}^{-1}$ consumption of oleic acid, value which is high compared to literature data. The $30 \%$ cake diet used by López Gallego (2002) provided 28 g oleic acid daily and induced a significant increase in oleic and stearic acids in perirenal fat ( 5 and $11 \%$, respectively), a non significant decrease of palmitic acid (6\%), and a major decrease of $41 \%$ in margaric acid when compared to the control diet. Arana et al. (2006) fed 23-kg lambs a diet containing 65 $\mathrm{g} \mathrm{EE} \mathrm{kg}^{-1}$ that supplied $34 \mathrm{~g}$ of oleic acid daily for $33 \mathrm{~d}$, as the corresponding calcium soap. Despite the protection of oleic acid by the soap, the authors did not detect any differences in the oleic acid content of subcutaneous or perirenal fat, nor in the Longuissimus dorsi muscle. They found no changes in palmitic acid and most other fatty acids of subcutaneous fat, but soap supplementation increased the concentration of stearic acid as it occurred in the present experiment. The authors concluded that to increase C18:1, a larger amount of oleic acid or a longer supplementation period would be required.

\section{Fatty acid profile}

Subcutaneous fat of the three treatments had distinct fatty acid profiles as shown by the results of all the statistical analyses, and to the extent that the discriminant analysis was able to correctly classify the 36 carcasses under study. If these results are repeatable, it would be feasible to correctly classify lamb carcasses produced by 


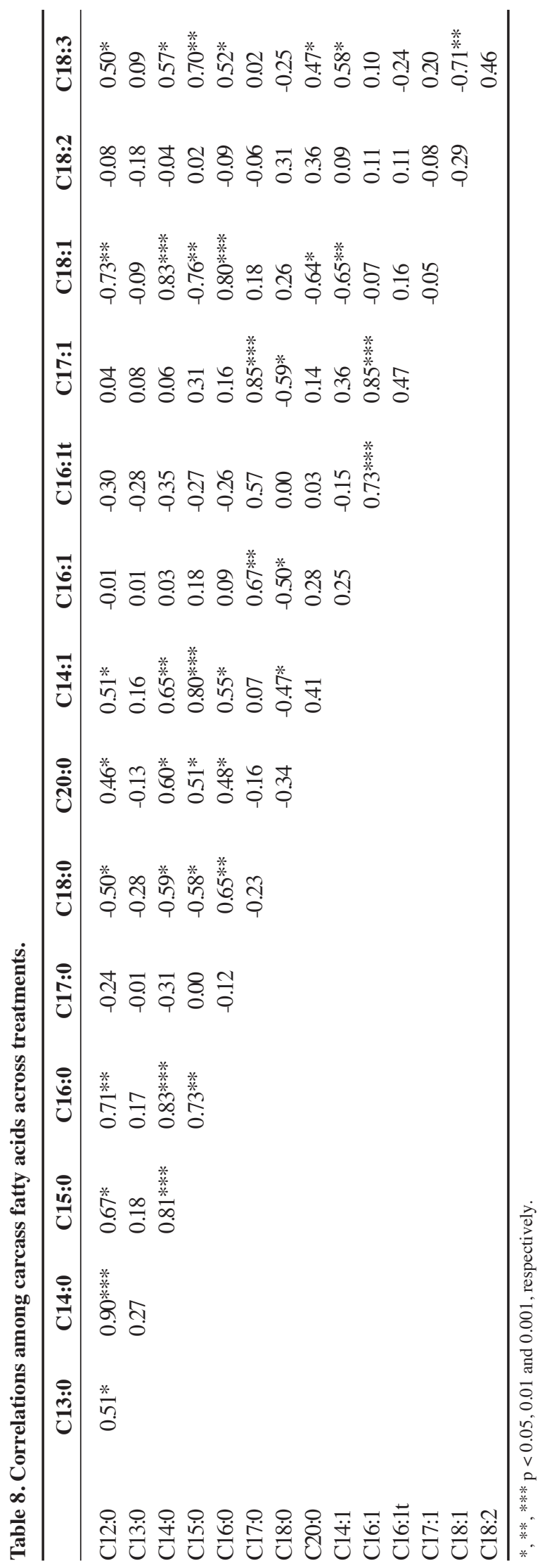

either one of the feeding strategies examined in the present experiment based on a conventional fatty acid profile of subcutaneous fat. This approach would be valuable for the monitoring and traceability of animals from different origins, but it needs further analysis with a larger and more varied group of animals. Principal component analysis indicated that the first two components that accounted for most of the variance can be associated with particular characteristics. PC1 can be referred to as the atherogenic component since it is dominated by medium chain saturated fatty acids and by the negative and important contribution of stearic and oleic acid. On the other hand, PC2 is the monounsaturated component and is dominated by monounsaturated fatty acids, plus an important contribution of C17:0, a minor, but constant component of sheep fat (Hansen et al., 1954). Lastly, PC3, identified as the PUFA component, is noteworthy for the contribution of long chain polyunsaturated fatty acids. In general, these results are highly comparable to those found by López Gallego (2002), in terms of the high proportion of total variance accounted for in the composition of the PCs, and of the importance of C17:0 in separating groups.

Ruminant meats, particularly lamb, have high concentrations of saturated fatty acids (Christie cited by Barber et al., 2000), with consequent negative implications for consumer health. Palmitic and oleic acid are the most important fatty acids, not only in subcutaneous fat, but also in important muscles such as the Longuissimus dorsi (Naht Dinh, 2006). Therefore, high oleic acid content of carcasses in the CAKE treatment and the high monounsaturated fatty acids (MUFA)/saturated fatty acids (SFA) ratio are interesting from the point of view of human health, and also for the implications that they can have as regards lipogenesis of other fatty acids in subcutaneous adipose and other tissues. This is important since subcutaneous adipose tissue constitutes the major adipose tissue of lambs (Kempster and Cuthberson, 1977; López cited by Velasco Villar, 1998), representing approximately $45-50 \%$ of the total subcutaneous, intermuscular, and intestinal (kidney and pelvic) fat. It also has a generally higher content of oleic acid than mesenteric and other fat (Palmquist et al., 2004).

Furthermore, the high ratio of oleic + stearic to palmitic acid in CAKE subcutaneous fat is also noticeable since Bonanome and Grundy (1988) suggested that stearic acid can be as effective as oleic acid in lowering blood cholesterol in human subjects. Oleic acid concentration in the subcutaneous fat of CAKE carcasses could have had two complementary origins. Part of the oleic acid could have come directly from the diet and escaping rumen hydrogenation. Daniel et al. (2004) compared a grass pellet diet with two levels of concentrate rations 
Table 9. Principal component analysis of the fatty acid profile of all carcasses.

\begin{tabular}{lcccc}
\hline Fatty acid & Component 1 & Component 2 & Component 3 & Component 4 \\
\hline C12:0 & 0.3157 & -0.1497 & -0.1435 & -0.1612 \\
C13:0 & 0.1042 & -0.0596 & -0.4174 & 0.2082 \\
C14:0 & 0.3605 & -0.0977 & -0.0692 & -0.1899 \\
C15:0 & 0.3532 & 0.0705 & -0.0322 & 0.1583 \\
C16:0 & 0.3320 & -0.1115 & -0.0726 & -0.2084 \\
C17:0 & -0.1112 & 0.4518 & -0.0895 & 0.2743 \\
C18:0 & -0.2288 & -0.2003 & 0.3884 & 0.2836 \\
C20:0 & 0.23558 & 0.1283 & 0.2756 & -0.4135 \\
C14:1 & 0.3081 & 0.1393 & 0.0020 & 0.2988 \\
C16:1 & 0.0423 & 0.5021 & 0.0022 & -0.2338 \\
C16:1 trans & -0.1512 & 0.3492 & 0.1991 & -0.3593 \\
C17:1 & 0.0687 & 0.5011 & -0.1728 & 0.0815 \\
C18:1 n9 & -0.3399 & 0.0985 & -0.2625 & 0.0290 \\
C18:2 n6 & 0.0426 & 0.0747 & 0.5947 & 0.1251 \\
C18:3 n3 & 0.2804 & 0.0543 & 0.2546 & 0.2785 \\
Others & 0.2721 & 0.1533 & 0.0475 & 0.3546 \\
Variance, fraction of total & 0.42 & 0.21 & 0.12 & 0.07 \\
\hline
\end{tabular}

and found that oleic acid in subcutaneous fat increased in concentrate diets, particularly at higher intakes, but differences in carcass oleic acid concentration were smaller than the difference in the diets. Furthermore, they reported that the concentration of oleic acid in the abomasum, although six times higher than in the grass diet, was less than the concentration found in the major adipose depots, arguing against the direct transfer from diet to tissues. This is in line with the present study where the difference in carcass oleic acid between CAKE and CONC treatments was high, but less than the difference in the respective diets. An alternative explanation is that de novo tissue synthesis of palmitic acid, followed by elongation of the chain to stearic acid, supplied the substrate to the rate-limiting stearoyl-CoA desaturase that catalyzed the transformation of stearic to oleic acid. The enzyme not only desaturates stearic acid, but it also uses a range of other substrates, including vaccenic acid, which is desaturated to rumenic acid (C18:2 cis-9, trans-11). Mosley et al. (2002) indicate that a small proportion of oleic acid, $3 \%$, resulted in vaccenic acid in the rumen.

This view is supported by Barber et al. (2000) who found a positive correlation between enzyme activity and the concentration of oleic acid in subcutaneous and epicardial tissues, but not in abdominal adipose tissues. The above-mentioned enzyme also results in rumenic acid (C18:2, cis-9, trans-11) from vaccenic acid, the linolenic acid isomer with the highest anticancerigenous activity. Thus, high enzyme activity correlated with high oleic acid contents offers the possibility of a parallel increase of endogenous origin CLA (Griinari et al., 2000). It should be noted that most of the rumenic acid does not occur from absorption but from endogenous synthesis in the adipocyte microsomes, using vaccenic acid as the immediate precursor (Griinari et al., 2000; Palmquist et al., 2004). Nevertheless, these PUFA would have to be determined in muscle, rather than in adipose tissue, since they are mostly found in phospholipids rather than in triglycerides (Aurousseau et al., 2004). Wood et al. (2003) indicated that phospholipids in steers are $12 \mathrm{x}$ higher in PUFA than in neutral lipids, possibly because adipose tissue has low SCD activity (Demirel et al., 2004), and because PUFA are scarcely incorporated into triglycerides (Sinclair, 2007).

Linolenic acid is the main PUFA found in forages (Palmquist et al., 2004) and inhibits liver SCD activity to a much greater extent than linoleic acid, which is prevalent in concentrate diets. This provides support for the difference in oleic acid between treatments in the present study originated, to a considerable extent, in endogenous synthetic processes. On the other hand, CAKE diet and resulting carcasses had a high concentration of oleic acid, although the differences between diets were greater than those found in the carcasses. It is unavoidable to infer that a significant proportion could have escaped rumen hydrogenation, particularly in the acid $\mathrm{pH}$, only partially buffered by a small supply of dietary bicarbonate that could have occurred in the rumen of concentrate-fed animals. Kelsey et al. (2003) suggested that the oleic/ (oleic+stearic) ratio is an index of SCD activity in 
subcutaneous fat. The authors reported ratios of 0.64-0.70 in high concentrate diets which compares well with the 0.69 found in the present study. This suggests that the enzyme activity must have been high in the CONC and CAKE treatments, but this view must be abated given the higher than anticipated ratio found in the GRAZE suckling lambs.

Regardless of the origin of the high concentration of oleic acid in CAKE carcasses, it is well established that MUFA and omega-3 PUFA decrease cholesterol absorption (reviewed by Wang, 2007), whereas palmitic acid leads to high platelet aggregation related to diets rich in MUFA, so that meat from lambs fed diets high in unexhausted olive cake can qualify as a functional or nutraceutical food, a hypothesis deserving further research. This view is supported by the palmitic/(oleic + stearic) ratio that, according to Rhee (cited by Banskalieva et al., 2000), is indicative of the atherogenic potential of foods, and for which there was a clear-cut difference in favor of CAKE. In fact, Minihane (2006) reported that for every $1 \%$ reduction in dietary SFA intake, there is an associated 3\% decrease in cardiovascular risk. Rodrigues et al. (2006) found that Suffolk lambs at 30-35\% maturity, equivalent to lambs in the present experiment, contained around 5\% subcutaneous fat and $9 \%$ intermuscular fat. Therefore, it would be expected that the desirable profile found in the subcutaneous fat of CAKE animals would also apply to muscle fat, the fraction of fat most likely to be consumed by humans.

In general, low forage diets decrease carcass stearic acid (Daniel et al., 2004; Palmquist et al., 2004), but this is a clearly opposite trend to the findings of the present study which showed nonsignificant differences between GRAZE and CONC, whereas there was a $21 \%$ increase of stearic acid in CAKE. In in vitro incubations, Mosley et al. (2002) found that $52 \%$ of the stearic acid was derived from oleic acid, as well as a high number of positional isomers of $\mathrm{C} 18: 1$. This is potentially important since Mosley et al. (2006) reported that approximately $80 \%$ of bovine milk CLA could originate from vaccenic acid.

Cabiddu et al. (2005) reviewed the literature as regards management of Mediterranean pastures and their potential effect of beneficial fatty acids on milk and cheese content, and showed that some forage species can favorably influence milk fat composition, but concluded that available evidence does not yet allow developing management strategies targeting the modification of the fatty acid profile of grazing animals in a consistent manner. The present study suggests that it would be worthwhile to investigate the effects of supplementing olive cake-based rations to grazing ewes and lambs in order to combine the benefits of high PUFAs derived from forages with high MUFAs from the cake.
If Kelsey's (2003) findings in dairy cows as regards the absence of a clear relationship between breed, parity, milk yield, and composition to CLA concentration can be applied to sheep, it would be expected that these, and related animal factors, would be of minor importance in determining some aspects of the fatty acid profile of major tissues. However, diet and rumen metabolism would have a predominant role in determining human health-related aspects of the quality of the final, marketable, animal product, including the Longissimus dorsi muscle (Daniel et al., 2004), which is an appealing hypothesis worthy of further research. Lastly, the important and clear-cut differences in the fatty acid profile of the three treatments, revealed by both discriminant and principal component analyses, support the view of Aurousseau et al. (2007) that these statistical techniques can play a role in the traceability of lamb meat.

\section{CONCLUSIONS}

Laboratory findings clearly suggest that dehydrated olive cake can be conserved for several months with no detriment to its lipid composition and quality. This is an important finding since production of olive cake is highly seasonal and restricted to 6-8 weeks per year, whereas its utilization as a ration ingredient could extend over several months.

The present results conclusively demonstrate that it is possible to significantly alter the fatty acid profile of lamb subcutaneous fat and possibly other fat deposits as well, through modifications in the feeding strategy. Infact, stall-feeding a conventional concentrate or olive cake-based ration induced considerable changes in the contents of many individual fatty acids, including decreased saturated fatty acid and increased monounsaturated fatty acid contents. These trends were emphasized by feeding with olive cake-based concentrate. On the other hand, carcasses of grazing, suckling lambs had a higher content of polyunsaturated fatty acids. Overall, the most notable change was the high increase in oleic acid when feeding olive cake, the improvement in the MFA/SFA ratio along with no change in the PUFA/SFA ratio associated with it.

\section{ACKNOWLEDGEMENTS}

This study was supported by grant FIA-PI-C-2005-1PO68 (FIA, Ministerio de Agricultura, Chile). The authors thank Ignacio García of GAYBA S.A. for supplying and processing the olive cake and for his input in this study, as well as John Alarcón Camacho of Natural Response S.A., Chile, for the polyphenol analyses. 


\section{RESUMEN}

Alimentación con alperujo modifica la composición de grasa subcutánea en corderos, con una nota en la resistencia del alperujo a degradación y peroxidación. El propósito del experimento aquí reportado fue determinar en qué grado se puede modificar la composición y calidad de la carcasa de corderos con el suministro de una ración basada en el alperujo de oliva, en comparación con una ración convencional o con el pastoreo directo. Se compararon tres tratamientos usando un diseño completamente al azar con 36 corderos machos Suffolk Down de partos únicos, y con edad y peso inicial de $80 \mathrm{~d}$ y $25 \mathrm{~kg}$, respectivamente. Los tres tratamientos consistieron en; (a) corderos lactantes mantenidos con sus madres en una pastura anual de tipo mediterráneo (GRAZE); (b) corderos destetados alimentados con una ración control (CONC), y (c) corderos destetados alimentados con una ración basada en alperujo (CAKE). Al final del período experimental de $28 \mathrm{~d}$ los corderos fueron sacrificados, se evaluaron parámetros de calidad de la carcasa y se tomaron muestras de grasa subcutánea para determinación del perfil de ácidos grasos. No hubo diferencias significativas en ganancia de peso, peso de la carcasa y en la mayoría de los parámetros de calidad de la canal. Por el contrario, se encontraron diferencias significativas y considerables en el contenido de varios ácidos grasos. Las reses de CAKE tuvieron menor contenido de ácido palmítico y mayor de ácidos esteárico y oleico. Los índices aterogénicos y trombogénicos mejoraron con el suministro de alperujo. Los análisis de componentes principales y análisis discriminante diferenciaron con efectividad los tratamientos de alimentación y se sugiere que podrían ser aplicables para propósitos de trazabilidad. Un experimento de laboratorio demostró que con o sin la adición de vitamina E, el alperujo seco no sufrió cambios considerables en la calidad de sus lípidos con el aumento en el tiempo de almacenamiento.

Palabras clave: ovino, alperujo, ácidos grasos, composición corporal.

\section{LITERATURE CITED}

Aguilar, C., R.R. Vera, P. Toro, R. Lira, J. Quenaya, F. Squella, et al. 2009. Performance of lambs fattened on annual Mediterranean pasture or fed a concentrate ration with or without olive oil cake. Anim. Feed Sci. Technol. (In press).

Aguilera, J.F.E., e E. Molina. 1986. Valorisation nutritive d'un grignon d'olive traité à la soude. Ann. Zootec. $35: 205-218$.
Amro, B., T. Aburjai, and S.Al-Khalil.2002. Antioxidative and radical scavenging effects of olive cake extract. Fitoterapia 73:456-461.

Anderson, J.M.L. 2001. Sheep meat: can we adapt to forthcoming demands? p. 11-17. In Rubino, R., and P. Morand-Fehr (eds.) Production systems and product quality in sheep and goats. Options Méditerranéennes: Série A. Séminaires Méditerrannées 46. Centre International de Hautes Études Agronomiques Méditerranéennes-Instituto Agronómico Mediterráneo de Zaragoza (CIHEAM-IAMZ), Zaragoza, Spain.

AOAC. 2007. Official methods of analysis. $18^{\text {th }}$ ed. Latimer, G.W., Jr., and W. Horwitz (eds.) AOAC International, Gaithersburg, Maryland, USA.

Arana, A., J.A. Mendizabal, M. Alzon, P. Eguinoa, M.J. Beriain, and A. Purroy. 2006. Effect of feeding lambs oleic acid calcium soaps on growth, adipose tissue development and composition. Small Rumin. Res. 63:75-83.

Aurousseau, B., B. Bauchart, E. Calichon, D. Micol, and A. Priolo. 2004. Effect of grass or concentrate feeding systems and rate of growth on triglyceride and phospholipid and their fatty acids in the $M$. longissimus thoracis of lambs. Meat Sci. 66:531541.

Aurousseau, B., B. Bauchart, E. Calichon, D. Micol, and A. Priolo. 2007. Indoor fattening of lambs raised on pasture. 2. Influence of stall finishing duration on triglyceride and phospholipid fatty acids in the longissiumus thoracis muscle. Meat Sci. 76:417-427.

Banskalieva, V., T. Sahlu, and A.L. Goetsch. 2000. Fatty acid composition of goat muscles and fat depots: a review. Small Rumin. Res. 37:255-268.

Barber, M.C., R.J. Ward, S.E. Richards, A.M. Salter, P.J. Buttery, R.G. Vernon, and M.T. Travers. 2000. Ovine adipose tissue monounsaturated fat content is correlated to depot-specific expression of the stearoylCoA desaturase gene. J. Anim. Sci. 78:62-68.

Bligh, E.G., and W.J. Dyer. 1959. A rapid method of total lipid extraction and purification. Can. J. Biochem. Phys. 37:911-917.

Bonanome, A., and S.M. Grundy. 1988. Effect of dietary stearic acid on plasma cholesterol and lipoprotein levels. New Engl. J. Med. 318:1244-1247.

Cabiddu, A., M. Canu, M. Decandia, R. Pompei, and G. Molle. 2004. The intake and performance of dairy ewes fed with different levels of olive cake silage in late pregnancy and suckling periods. p. 197-202. In Nutrition and feeding strategies of sheep and goats under harsh climates. Centre International de Hautes Études Agronomiques Méditerranéennes-Instituto Agronómico Mediterráneo de Zaragoza (CIHEAMIAMZ), Zaragoza, Spain. 
Cabiddu, A., M. Decandia, M. Addis, G. Piredda, A. Pirisi, and G. Molle. 2005. Managing Mediterranean pastures in order to enhance the level of beneficial fatty acids in sheep milk. Small Rumin. Res. 59:169-180.

Cañeque, V., y C. Sañudo (eds.) 2005. Estandarización de las metodologías para evaluar la calidad del producto (animal vivo, canal, carne y grasas) en los rumiantes. Instituto Nacional de Investigación y Tecnología Agraria y Alimentaria (INIA), Madrid, España.

Chiofalo, B., L. Liotta, A. Zumbo, and V. Chiofalo. 2004. Administration of olive cake for ewe feeding: Effect on milk yield and composition. Small Rumin. Res. 55:169-176.

Daniel, Z.C.T.R., R.J. Wynn, A.M. Salter, and P.J. Buttery. 2004. Differing effects of forage and concentrate diets on the oleic acid and conjugated linoleic acid content of sheep tissues: The role of stearoyl-CoA desaturase. J. Anim. Sci. 82:747-758.

De Leonardis, V., V. Macciola, G. Lembo, A. Aretini, and A. Nag. 2007. Studies on oxidative stabilization of lard by natural antioxidants recovered from olive-oil mill wastewater. Food Chem. 100:998-1004.

Demeyer, D., and M. Doreau. 1999. Targets and procedures for altering ruminant meat and milk lipids. P. Nutr. Soc. 58:593-607.

Demirel, G., J.D. Wood, and M. Enser. 2004. Conjugated linoleic acid content of the lamb muscle and liver fed different supplements. Small Rumin. Res. 53:23-28.

FAO. 2007. FAO statistical database. FAO, Rome, Italy. Available at http://www.fao.org/corp/statistics/en/ (accessed 15 November 2008).

Folch, J., M. Lee, and G.H.S. Stanley. 1956. A simple method for the isolation and purification of total lipids from animal tissues. J. Biol. Chem. 226:497-509.

Givens, D.I. 2005. The role of animal nutrition in improving the nutritive value of animal-derived foods in relation to chronic disease. P. Nutr. Soc. 64:395402.

Griinari, J.M., B.A. Corl, S.H. Lacy, P.Y. Chouinard, K.V.V. Nurmela, and D.E. Bauman. 2000. Conjugated linoleic acid is synthesized endogenously in lactating dairy cows by DELTA9-desaturase. J. Nutr. 130:22852291.

Hadjipanayiotou, M. 1994. Voluntary intake and performance of ruminant animals offered poultry litter-olive cake silage. Livest. Res. Rural Dev. Volume 6. $\mathrm{N}^{\circ}$ 2. Available at http://www.lrrd.org/ lrrd6/2/cyprus2.htm (accessed 15 January 2008).

Halliwell, B. 2001. Food-derived antioxidants: how to evaluate their importance in food and in vivo. p. 1-37. In Cadenas, E., and L. Packer (eds.) Handbook of antioxidants: revised and expanded. Marcel Dekker, New York, USA.
Hansen, R.P., F.B. Shorland, and N.J. Cooke. 1954. The occurrence of n-heptadecanoic acid (Margaric acid) in hydrogenated mutton fat. J. Biol. Chem. 58:513515.

INN. 2001. Grasas y aceites animales y vegetales. Análisis de esteres metílicos por cromatografía de gas. Norma Chilena NCh 2550. Of 2001. ISO 5508. Norma Chilena \#497-509. Instituto Nacional de Normalización, Santiago, Chile.

Junta de Andalucía. 2001. Posibles impactos de la crisis del aceite de orujo de oliva sobre el sector oleícola andaluz. Available at http://www.juntadeandalucia. es/agriculturaypesca/prospectiva/Olivar3_doc.pdf (accessed 22 November 2007).

Kelsey, J.A., B.A. Corl, R.J. Collier, and D.E. Bauman. 2003. The effect of breed, parity, and stage of lactation on conjugated linoleic acid (CLA) in milk fat from dairy cows. J. Dairy Sci. 86:2588-2597.

Kempster, A.J., and A. Cuthberson. 1977. A survey of the carcass characteristics of the main types of British lamb. Anim. Prod. 25:165-179.

Khorchani, T., M. Hammaid, H. Hammami, and B. Ben Rouina. 1997. Use of olive by-products in the nutrition of lambs in southern Tunisia. p. 99102. In Lindberg, J.E., H.L. Gonda, and I. Ledin (eds.) Recent advances in small ruminant nutrition. Options Méditerranéennes: Série A. Séminaires Méditerranéens 34. Centre International de Hautes Études Agronomiques Méditerranéennes-Instituto Agronómico Mediterráneo de Zaragoza (CIHEAMIAMZ), Zaragoza, Spain.

López Gallego, F. 2002. El alpeorujo en la alimentación de corderos. 307 p. Thesis Dr. Universitat de Lleida, Lleida, España.

MacRae, J., L. O’Reilly, and P. Morgan. 2005. Desirable characteristics of animal products from a human health perspective. Livest. Prod. Sci. 94:95-103.

Makkar, H.P.S. 2003. Quantification of tannins in tree and shrub foliage. A laboratory manual. 116 p. Kluwer Academic Publishers, Dordrecht, The Netherlands.

Minihane, A.M. 2006. The role of meat lipids in human health. P. Brit. Soc. Anim. Sci. 2006:201.

Molina Alcaide, Y.E., D.R. Morales García, A. Yañez Ruiz, A. Mourmen, y A.I. Martín García. 2005. Aprovechamiento de los residuos de las industrias del aceite de oliva mediante su uso como alimentos para rumiantes. Foro del Olivar y el Medio Ambiente. Available at http://www.expoliva.com/expoliva2005/ simposium $/ \mathrm{com} \cdot$ asp $?$ anio $=2005 \& \operatorname{codig} \mathrm{o}=\mathrm{OLI}$, Código OLI-52 (accessed 15 July 2007).

Mosley, E.E., G.L. Powell, M.B. Biley, and T.C. Jenkins. 2002. Microbial biohydrogenation of oleic acid to trans isomers in vitro. J. Lipid Res. 43:290-296. 
Mosley, E.E., B. Shafi, P.J. Moate, and M.A. McGuire. 2006. cis-9, trans-11 Conjugated linoleic acid is synthesized directly from vaccenic acid in lactating dairy cattle. J. Nutr. 136:570-575.

Naht Dinh, T.T. 2006. Lipid and cholesterol composition of the longissimus muscle from Angus, Brahman and Romosinuano. 153 p. Thesis M.S. Texas Tech University, Lubbock, Texas, USA.

Naz, S., H. Sheikh, R. Siddiqi, and S.A. Sayeed. 2004. Oxidative stability of olive, corn and soybean oil under different conditions. Food Chem. 88:253-259.

NRC. 2002. Scientific advances in animal nutrition: Promise for the next century. 102 p. Committee on Animal Nutrition, Board on Agriculture and Natural Resources, National Research Council (NRC), Washington, D.C., USA.

NRC. 2007. Nutrient requirements of small ruminants: sheep, goats, cervids, and New World camelids. 384 p. Committee on Animal Nutrition, Board on Agriculture and Natural Resources, National Research Council (NRC), Washington D.C., USA.

Olive Oil Source. 2007. Waste from oil production. Available at http://oliveoilsource.com/olive_waste. htm\#Overview (accessed 22 November 2007).

Ovalle, M.C., y F. Squella. 1996. Terrenos de pastoreo con pastizales anuales en el área de influencia climática mediterránea. p. 429-466. In Ruiz, N.I. (ed.) Praderas para Chile. Instituto de Investigaciones Agropecuarias (INIA), Santiago, Chile.

Palmquist, D.L., N.R. St-Pierre, and K.E. McClure. 2004. Tissue fatty acid profiles can be used to quantify endogenous rumenic acid syntehsis in lambs. J. Nutr. 134:2407-2414.
Puchal Mas, F., and J. Mascarell. 1999. New strategies in animal feeding to improve consumer acceptance of animal products. p. 33-47. In Brufau, J., and A. Tacon (eds.) Feed manufacturing in the Mediterranean region. Recent advances in research and technology. Centre International de Hautes Études Agronomiques Méditerranéennes-Instituto Agronómico Mediterráneo de Zaragoza (CIHEAM-IAMZ), Zaragoza, Spain.

Rodrigues, S., V. Cadavez, and A. Teixeira. 2006. Breed and maturity effects on Churra Galega, Bragançana and Suffolk lamb carcass characteristics: Killing-out proportion and composition. Meat Sci. 72:288-293.

SAS Institute. 2002. SAS/STAT user's guide version 9. SAS Institute Inc., Cary, North Carolina, USA.

Sinclair, A. 2007. Nutritional manipulation of the fatty acid composition of sheep meat: a review. J. Agric. Sci. 145:419-434.

TDC-OLIVE. Undated. Legislación europea relacionada con el sector olivarero y análisis de peligros y puntos de control críticos (APPCC). Available at http://www. asajasev.es/asp/files/Legislación europea relacionada con el sector olivarero y APPCC.pdf (accessed 22 November 2007).

Velasco Villar, S. 1998. Caracterización de los depósitos adiposos de corderos lechales en función de diversos parámetros productivos. Thesis Dr. Universidad Complutense, Madrid, España.

Wang, D.Q. 2007. Regulation of intestinal cholesterol absorption. Annu. Rev. Physiol. 69:221-248.

Wood, J.D., R.I. Richardson, G.R. Nute, A.V. Fisher, M.M. Campo, E. Kasapidou, et al. 2003. Effects of fatty acids on meat quality: a review. Meat Sci. 66:2132. 